\title{
ASTAXANTHIN UNTUK KESEHATAN KARDIOVASKULAR
}

\author{
Rana Salsabila Putri Laja \\ Fakultas Kedoktern, Universitas Lampung, Jl. Prof. DR. Ir. Sumatri Brojonegoro No.1, Gedong Meneng, \\ Kec. Rajabasa, Kota Bandar Lampung, Lampung, Indonesia 35145 \\ Ranasalsabila27@gmail.com (+6282282629131)
}

\begin{abstract}
ABSTRAK
Penyakit kardiovaskular adalah penyebab utama kematian di seluruh dunia. Adanya dislipidemia, gangguan toleransi glukosa, dan hipertensi dengan akumulasi lemak visceral yang disebut sindrom metabolik, meningkatkan risiko penyakit kardiovaskular. Sindrom metabolik sering ditandai dengan stres oksidatif, gangguan keseimbangan antara produksi reactive oxygen species dan pertahanan antioksidan. Sementara itu, astaxanthine diketahui memiliki karakteristik antioksidan yang kuat, yang telah dilaporkan melampaui karakteristik $\beta$-karoten atau bahkan $\alpha$ tokoferol. Penelitian ini merupakan literature review yang melibatkan sebanyak 20 sumber pustaka dengan kata kunci yang digunakan antara lain 'astaxanthin, cardiovascular disease dan xanthophyll carotenoid' dengan tahun terbit antara 2006-2020. Abstrak dan full text jurnal dibaca dan dicermati, kemudian dilakukan analisis terhadap isi yang terdapat dalam tujuan penelitian dan hasil/temuan penelitian. Beberapa penelitian menunjukkan adanya beberapa manfaat yang dapat secara langsung atau tidak langsung dari astaxanthin berkaitan dengan potensi antioksidannya, termasuk kemampuannya untuk mengurangi atau menetralkan produksi ROS, sehingga meningkatkan aktivitas enzim pembersih radikal. Astaxanthin juga berperan sebagai anti inflamasi dan berperan dalam metabolisme lipid melalui efek hipokolesterolemik serta melindungi dari iskemia reperfusi. Astaxanthin di ketahui dapat memberikan manfaat bagi kesehatan kardiovaskular melalui berbagai mekanisme seperti peran antioksidan yang lebih baik, anti inflamasi, efek hipokolesterolemik dalam metabolisme lipid dan melindungi dari iskemia reperfusi.
\end{abstract}

Kata kunci: astaxanthin; penyakit kardiovaskular

\section{ASTAXANTHIN FOR CARDIOVASKULAR HEALTH}

\begin{abstract}
Cardiovascular disease is the leading cause of death worldwide. The presence of dyslipidemia, impaired glucose tolerance, and hypertension with accumulation of visceral fat, known as the metabolic syndrome, increases the risk of cardiovascular disease. Metabolic syndrome is often characterized by oxidative stress, a disruption in the balance between production of reactive oxygen species and antioxidant defenses. Meanwhile, astaxanthine is known to have strong antioxidant characteristics, which have been reported to go beyond the characteristics of $\beta$ carotene or even $\alpha$-tocopherol. This research is a literature review involving as many as 20 literature sources with the keywords used, among others, "astaxanthin, cardiovascular disease and xanthophyll carotenoid" with publication years between 2006-2020. Abstracts and full text journals are read and examined, then an analysis is carried out of the contents contained in the research objectives and the results / research findings. Several studies have shown that there are several direct or indirect benefits of astaxanthin related to its antioxidant potential, including its ability to reduce or neutralize ROS production, thereby increasing the activity of radical scavenging enzymes. Astaxanthin also acts as an anti-inflammatory and plays a role in lipid metabolism through its hypocholesterolemic effect and protects against reperfusion ischemia. Astaxanthin is known to provide benefits for cardiovascular health through various mechanisms
\end{abstract}


such as the role of better antioxidants, anti-inflammatory, hypocholesterolemic effects in lipid metabolism and protects against reperfusion ischemia.

Keywords: astaxanthin; cardiovascular disease

\section{PENDAHULUAN}

Penyakit kardiovaskuler merupakan penyebab terbesar morbiditas dan mortalitas baik di negara maju maupun berkembang. Tingkat penyakit kardiovaskular yang terus meningkat di negara berkembang adalah salah satu masalah kesehatan masyarakat yang paling relevan saat ini (Alam et al., 2018). Penyakit kardiovaskular (cardiovascular diseasel CVD) merupakan konsekuensi dari berbagai gangguan pada tubuh seperti jaringan adiposa perut yang berlebihan, hipertensi, dislipidemia, dan intoleransi glukosa yang meningkatkan risiko terjadinya peristiwa kardiovaskular seperti stroke dan serangan jantung (Garcia-Arellano et al., 2019). Selain itu, peningkatan kejadian CVD selama 3 dekade terakhir telah menjadi prioritas kesehatan dan sosial ekonomi, serta kebutuhan untuk pencegahan kejadian CVD melalui modifikasi gaya hidup (Doughty et al., 2017).

Perkembangan CVD terkait dengan pola nutrisi yang tidak sehat antara lain asupan natrium dan makanan olahan yang berlebihan, konsumsi gula berlebih dan lemak yang tidak sehat, asupan rendah buah dan sayuran, konsumsi alkohol, stres, dan merokok serta gaya hidup yang tidak banyak bergerak (Lanier et al., 2016). Dengan demikian, banyak bukti ilmiah telah menjelaskan bagaimana intervensi diet, dan aktivitas fisik, mungkin menjadi faktor terpenting untuk pencegahan CVD dan dapat mengurangi penyakit jantung. Karena jumlah individu yang lebih tua terus meningkat, penting untuk memahami mekanisme patofisiologis dari perubahan metabolik untuk mengembangkan intervensi yang dapat dengan mudah diterapkan untuk mencegah penyakit tidak menular, seperti CVD, yang secara signifikan mengubah kualitas hidup, meningkatkan morbiditas dan kematian dan, juga, biaya sosial ekonomi (Migliaccio et al., 2020).

Status oksidatif dan profil fisiologis sistem kardiovaskular merupakan elemen penting dalam mengevaluasi perkembangan sejumlah penyakit kardiovaskular (CVD), misalnya hipertensi. Di sisi lain, radikal bebas dan stres oksidatif dilaporkan memainkan peran penting dalam patogenesis berbagai kondisi penyakit jantung, seperti cedera iskemiareperfusi, gagal jantung kongestif, penyakit arteri koroner, dan hipertensi. Misalnya pada hipertensi, dikaitkan dengan perubahan struktural pada pembuluh darah resisten yang dikenal sebagai 'remodeling', dan dianggap sebagai proses kompleks yang mungkin melibatkan peningkatan (hipertrofi), penurunan (hipotrofi), atau penataan ulang (eutrofi) bahan dinding pembuluh darah. Pada sebagian besar model hewan hipertensi,diameter internal arteri umumnya berkurang dan rasio dinding lumen meningkat di arteri kecil jika dibandingkan dalam kondisi biofisik yang setara. Beberapa senyawa antioksidan dan diet telah terbukti efektif dalam mengurangi kerusakan oksidatif pada tikus, terutama pada penyakit jantung (Hussein et al., 2006).

Berbagai pengobatan untuk mengatasi permasalahan pada penyakit kardiovaskular masih terus diperbaharui, tidak hanya dengan obat- 
obatan sintetik, namun juga obat alam berbasis senyawa bioaktif tumbuhan tingkat tinggi. Sejumlah studi juga menunjukkan bahwa pigmen alami, yang diproduksi oleh tumbuhan tingkat tinggi ataupun rendah, juga mampu memberikan manfaat terapi hampir serupa untuk membantu menurunkan prevalensi penyakit kardiovaskular (Salim et al., 2016).

Astaxanthin (3,3-dihydroxy-b, bcarotene-4,4-dione) termasuk dalam subclass xanthophyll karotenoid (Santos et al., 2012). Alga hijau, Haematococcus pluvialis mengandung astaxanthin tertinggi (hingga 4\% / g, berat kering), dan merupakan sumber utama astaxanthin alami (Yang et al., 2011). Keanekaragaman hayati yang ada di Indonesia menjadi peluang bagi ilmuwan dan industri untuk melakukan pengembangan dan inovasi produk kesehatan yang berasal dari bahan alami. Perkembangan riset telah menunjukkan bahwa metabolit sekunder lain berupa pigmen alami terutama golongan karotenoid xantofil seperti astaxanthin, terbukti memiliki bioaktivitas yang berperan memperbaiki profil lemak tubuh (Salim et al., 2016). Karena sifat fisikokimia dan nilai tambahnya yang tinggi, astaxanthin banyak digunakan dalam aditif pakan, kosmetik dan farmasi (Santos et al., 2012). Selain itu, astaxanthin dianggap efektif melawan resistensi insulin, hiperlipidemia, steatohepatitis, dan diabetes (Ni et al., 2015).

Astaxanthin juga dapat memainkan peran kunci dalam mencegah infark miokard dengan menghambat cedera jaringan jantung dengan aktivitas antioksidannya. Astaxanthin dilaporkan efektif dalam mencegah sindrom metabolik dan meningkatkan kadar adiponektin, meningkatkan high-density lipoprotein (HDL) dan menurunkan trigliserida plasma dan asam lemak nonesterifikasi, serta menurunkan ukuran sel lemak pada tikus (Alam et al., 2018). Oleh karena itu, studi literatur ini bertujuan untuk menilik peran astaxanthin untuk kesehatan kardiovaskular, yang sumber alaminya banyak ditemukan di Indonesia sehingga dapat memberikan manfaat besar bagi masyarakat.

\section{METODE}

Penelitian ini merupakan studi literature review, yang menyajikan kembali materi yang diterbitkan sebelumnya, dan melaporkan fakta atau analisis baru. Penelusuran sumber pustaka dalam artikel ini melalui database PubMed dan Google Scholar. Sumber pustaka yang digunakan dalam penyusunan melibatkan 20 pustaka dengan kata kunci yang digunakan dalam penelusuran antara lain 'astaxanthin, cardiovascular disease dan xanthophyll carotenoid' dengan tahun terbit antara 2006-2020. Pemilihan artikel sumber pustaka dilakukan dengan melakukan peninjauan pada judul, abstrak dan hasil yang membahas manfaat astaxanthin untuk kesehatan kardiovaskular. Abstrak dan full text jurnal dibaca dan dicermati, kemudian dilakukan analisis terhadap isi yang terdapat dalam tujuan penelitian dan hasil/temuan penelitian. Dilakukan koding terhadap isi jurnal yang direview berdasarkan garis besar atau inti dari penelitian tersebut yang dilakukan dengan mengurai dalam sebuah kalimat, dan jika sudah terkumpul kemudian dicari persamaan dan perbedaan pada masing-masing penelitian lalu dibahas untuk menarik kesimpulan. Hasil studi literatur ini berupa publikasi yang relevan. 


\section{HASIL}

Penelitian oleh Hussein et al (2006) dengan memberikan astaxanthin pada parameter oksidatif pada tikus hipertensi spontan (SHR), melihat tingkat produk akhir oksida nitrat (NO), nitrit / nitrat (NO2 / NO3) dan peroksidasi lipid. Pemberian astaxanthin oral secara signifikan mengurangi tingkat plasma $\mathrm{NO} 2 / \mathrm{NO} 3$ dibandingkan dengan kontrol $(\mathrm{p}<0.05)$. Tingkat peroksidasi lipid, juga diamati berkurang pada kelompok yang mendapat astaxanthin. Selain itu, terdapat penurunan yang signifikan pada pita elastin di aorta tikus $(\mathrm{p}<0.05)$ yang juga secara signifikan menurunkan rasio udara (dinding: lumen) dari arteri koroner. Astaxanthin dapat memodulasi kondisi oksidatif dan dapat meningkatkan elastin vaskular dan ketebalan dinding arteri pada hipertensi (Hussein et al., 2006).

Dalam penelitian lain oleh Deng et al (2017), pemberian astaxanthin $(30 \mathrm{mg} /$ $\mathrm{kg}$ ) pada tikus hiperlipidemia dapat mengurangi koagulasi darah dan agregasi platelet dan meningkatkan aktivitas fibrinolitik pada tikus hiperlipidemia. Mekanisme yang mendasari yaitu terkait dengan penurunan kadar lipid, produksi antioksidan dan perlindungan sel endotel. Astaxanthin juga terlibat dalam menjaga keseimbangan tissue-type plasminogen activator (t-PA)/ type-1 plasminogen activator inhibitor (PAI1), NO / ROS dan tromboksan A2 (TXA2) / prostasiklin (PGI2) in vivo (Deng et al., 2017).

Sejalan dengan penelitian tersebut, Alam et al (2018) juga melakuan studi untuk melihat efek astaxanthin pada infark miokard yang diinduksi isoproterenol (ISO) dan hipertrofi jantung pada tikus. Pengobatan astaxanthin mencegah peningkatan berat basah jantung dan menurunkan infiltrasi sel inflamasi dan fibrosis. Efek perlindungan astaxanthin dikaitkan dengan reduksi radikal bebas dengan meningkatkan fungsi enzim antioksidan, serta normalisasi dan / atau penekanan penanda stres oksidatif yang meningkat, seperti malondialdehida (MDA), oksida nitrat (NO), dan produk oksidasi protein lanjutan (APOP) pada tikus yang diberi isoprotenerol. Isoproterenol adalah bahan kimia yang banyak digunakan dalam studi toksikologi untuk menginduksi cedera otot jantung. Astaxanthin juga menurunkan aktivitas aspartate transaminase (AST), alanine transaminase (ALT), dan kreatinin kinase otot / otak (CK-MB) pada tikus yang diberi ISO. Sehingga, astaxanthin dapat melindungi jaringan jantung tikus yang diberikan ISO melalui penekanan stres oksidatif dan peningkatan fungsi enzim antioksidan. (Alam et al., 2018).

Sementara itu, Choi et al (2011) mengamati efek astaxanthin pada stres oksidatif pada orang dewasa yang kelebihan berat badan dan obesitas di Korea. Pada sebanyak 23 orang dewasa dengan BMI> 25,0 kg / m2, secara acak dibagi menjadi dua kelompok dosis, astaxanthin $5 \mathrm{mg}$ dan $20 \mathrm{mg}$ sekali sehari selama 3 minggu. Malondialdehyde (MDA), isoprostane (ISP), superoxide dismutase (SOD) dan total antioxidant capacity (TAC), sebagai penanda stres oksidatif, diukur pada awal dan 1, 2 dan 3 minggu setelah pemberian ASX. Dibandingkan dengan baseline, tingkat MDA (sebesar $34,6 \%$ dan 35,2\%) dan ISP (sebesar $64,9 \%$ dan $64,7 \%$ ) secara signifikan diturunkan, sedangkan SOD (sebesar $193 \%$ dan 194\%) dan TAC (sebesar $121 \%$ dan 125\%). meningkat secara signifikan dalam dua kelompok dosis setelah intervensi 3 minggu. Sehingga 
studi ini mengungkapkan bahwa suplementasi astaxanthin selama 3 minggu memperbaiki biomarker stres oksidatif dengan menekan peroksidasi lipid dan merangsang aktivitas sistem pertahanan antioksidan (Choi et al., 2011).

Dalam penelitian lain, Tsai et al mengamati efek astaxanthin pada penghambatan akumulasi lipid dalam adiposit 3T3-L1. Adiposit 3T3-L1 diberikan 0-25 $\mu \mathrm{g} / \mathrm{mL}$ astaxanthin selama 0-48 jam. Hasil penelitian menunjukkan bahwa astaxanthin secara signifikan menurunkan oil Red $O$ stained material (OROSM), akumulasi trigliserida intraseluler, dan aktivitas gliserol 3-fosfat dehidrogenase (GPDH) pada adiposit 3T3-L1 ( $\mathrm{p}<0,05)$. Pada tingkat molekuler, astaxanthin secara signifikan menurunkan ekspresi mRNA dari reseptor yang diaktifkan proliferator peroksisom- $\gamma$ (peroxisome proliferator-activated receptor- $\gamma$ /PPAR $\gamma$ ) dalam adiposit 3T3-L1 (p $<0,05)$. Selain itu, gen target PPAR $\gamma$ pada penghambatan lipogenesis, seperti Asetil-KoA karboksilase (ACC), sintase asam lemak (fatty acid synthase/ FAS), protein pengikat asam lemak (aP2), cluster of differentiation 36 (CD36), dan lipoprotein lipase (LPL) dalam adiposit 3T3-L1 menurun secara signifikan (p <0,05). Hasil ini menunjukkan bahwa astaxanthin secara efisien menekan akumulasi lipid dalam adiposit 3T3-L1 dan berhubungan dengan penurunan regulasi gen terkait lipogenesis dan akumulasi trigliserida dalam adiposit 3T3-L1. Oleh karena itu astaxanthin dapat dikembangkan sebagai bahan nutraceutical yang potensial untuk pencegahan obesitas yang menjadi risiko CVD (Tsai et al., 2020).

\section{PEMBAHASAN}

Stres oksidatif dan peradangan menjadi faktor risiko kardiovaskular bersamaan faktor lain meliputi hiperlipidemia, riwayat keluarga, merokok dan hipertensi. Selain itu, pengurangan asupan antioksidan dikaitkan dengan adanya stres oksidatif dan peradangan. Studi menunjukkan asupan makanan atau suplementasi dengan vitamin E dan $\beta$-karoten yang lebih tinggi dikaitkan dengan penyakit kardiovaskular yang lebih sedikit. Manusia tidak dapat mensintesis karotenoid dan harus mendapatkannya dalam sumber makanan seperti alga, tumbuhan dan jamur. Berdasarkan struktur kimianya, karotenoid diklasifikasikan menjadi dua jenis yaitu karoten dan xantopil. Likopen dan $\beta$-karoten adalah contoh karoten karotenoid. Lutein, canthaxanthin, zeaxanthin, violaxanthin, capsorubin dan astaxanthin adalah karotenoid xanthopil (Fassett \& Coombes, 2012).

Studi klinis pada manusia telah menggunakan astaxanthin yang diberikan secara oral dengan dosis mulai dari $4 \mathrm{mg}$ hingga $100 \mathrm{mg} /$ hari. Dalam penelitian eksperimental dan manusia, astaxanthin tampaknya dapat ditoleransi dengan baik, dan tidak ada toksisitas penting yang telah dijelaskan. Hubungan dosis-respons non-linier dan absorpsi selektif isomer $\mathrm{Z}$ juga diamati, dan waktu paruh eliminasi plasma diperkirakan $52 \sim 40$ jam. Kehadiran lemak makanan meningkatkan asimilasi astaxanthin di usus kecil (Kishimoto et al., 2016).

Stres oksidatif terlibat sebagai mekanisme penting di mana peningkatan produksi ROS atau pertahanan antioksidan yang tidak memadai dapat menyebabkan lesi pada jantung. Pemberian isoproterenol pada 
hewan coba menghasilkan disfungsi kardiovaskular dengan menginduksi stres oksidatif yang berlebihan dan peradangan di jantung. ROS seperti oksida nitrat, superoksida, dan peroksinitrit menyebabkan kerusakan parah pada jaringan sistem kardiovaskular. Pemberian astaxanthin meningkatkan pertahanan antioksidan serta menghambat peroksidasi lipid dan mencegah kebocoran enzim penanda cedera miosit dari jantung pada tikus yang diinduksi isoproterenol (Alam et al., 2018).

Peningkatan kadar kolesterol total, LDL dan trigliserida, atau penurunan kadar HDL, dapat mengindikasikan dislipidemia atau peningkatan risiko CVD. Bhuvaneswari et al (2010) menunjukkan bahwa pemberian astaxanthin pada tikus laboratorium, kadar kolesterol plasma dan triasilgliserol menjadi berkurang secara signifikan (Bhuvaneswari et al., 2010). Mekanisme yang mendasari efek hipokolesterolemik tersebut berhubungan dengan aktivasi alfa reseptor aktif proliferator peroksisom (PPAR), penghambatan gamma PPAR dan pensinyalan AktmTORC1. Selain itu, suplementasi astaxanthin juga telah dilaporkan menghasilkan peningkatan ekspresi dari satu set gen tertentu. Ini termasuk gen yang mengkode reseptor LDL, 3-hidroksi-3- metil glutaryl CoA reduktase dan sterol regulator element binding protein 2, yang semuanya mengatur metabolisme kolestrol hati; serta karnitin palmitoyltransferase-1 dan asil-CoA oksidase, keduanya penting dalam oksidasi $\beta$ lipid (Xia et al., 2020).

Karotenoid mengandung ikatan rangkap terkonjugasi panjang dalam rantai poliena yang bertanggung jawab atas aktivitas antioksidan dengan menghilangkan oksigen tunggal dan membersihkan radikal untuk menghentikan reaksi berantai. Pada astaxanthin, mengandung rantai poliena terkonjugasi di tengahnya dan gugus hidroksi serta keto pada setiap cincin ionon. Karena struktur molekulnya yang unik, astaxanthin menunjukkan aktivitas biologis yang lebih baik daripada antioksidan lainnya, karena dapat terhubung dengan membran sel dari dalam ke luar. Rantai poliena di astaxanthin menjebak radikal di membran sel, sedangkan cincin terminal astaxanthin dapat mengambil radikal baik di permukaan maupun di bagian dalam membran sel (Kishimoto et al., 2016).



Gambar 1. Orientasi transmembran dari astaxanthin (Kishimoto et al., 2016).

Peradangan kronis juga merupakan faktor patofisiologis utama pada banyak penyakit, seperti diabetes, hipertensi dan aterosklerosis. Menghambat 
produksi ROS intraseluler adalah cara umum untuk menekan sinyal proinflamasi, dan dengan demikian modulator keseimbangan redoks dianggap sebagai pengatur utama respon inflamasi. Makrofag memainkan peran sentral dalam perkembangan inflamasi dan aterosklerosis pada CVD. Serapan yang dimediasi reseptor scavenger dari LDL teroksidasi oleh makrofag mengarah pada pembentukan sel busa dan perkembangan plak aterosklerotik. Reseptor scavenger kelas A (SR-A) dan CD36 bertanggung jawab atas sebagian besar serapan LDL teroksidasi oleh makrofag, menunjukkan peran pro-aterogenik SRA dan CD3. Selain itu, dalam keadaan inflamasi, makrofag menghasilkan enzim pemecah matriks dalam jumlah berlebih, sitokin / kemokin proinflamasi, oksida nitrat (NO), dan siklooksigenase-2 (COX-2).

Matriks metaloproteinase (MMPs), keluarga endopeptidase yang bergantung pada $\mathrm{Zn} 2+$, bertanggung jawab atas degradasi sebagian besar protein matriks ekstraseluler, dan hal tersebut memediasi renovasi jaringan dalam berbagai kondisi patologis. Ekspresi MMP meningkat pada lesi aterosklerotik dan terkait dengan melemahnya dinding vaskular karena degradasi matriks ekstraseluler (Kishimoto et al., 2016). Macedo et al (2010) menunjukkan bahwa astaxanthin secara signifikan mengurangi produksi sitokin pro-inflamasi (TNF- $\alpha$ dan IL-6) pada neutrofil yang terstimulasi LPS [38]. Studi tersebut juga mengungkapkan bahwa astaxanthin meningkatkan kapasitas fagositik dan mikrobisidal neutrofil dan menekan produksi anion superoksida dan hidrogen peroksida, yang mungkin dimediasi oleh kalsium yang dilepaskan dari penyimpanan intraseluler dan produksi NO (Kishimoto et al., 2016; MacEdo et al., 2010).

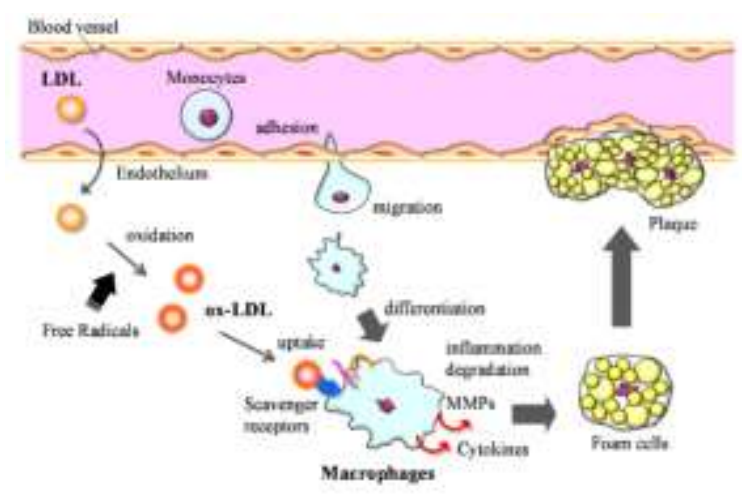

Gambar 2. Peran makrofag dalam perkembangan aterosklerosis (Kishimoto et al., 2016)

Iskemia-reperfusi adalah proses inflamasi kompleks yang mencakup stres oksidatif utama yang disebabkan oleh iskemia dan hipoksia. Curek et al (2010) menemukan bahwa pengobatan astaxanthin secara signifikan menurunkan konversi xanthine dehydrogenase $(\mathrm{XDH})$ menjadi xanthine oxidase (XO), yang mengurangi tingkat stres oksidatif pada cedera hepatoseluler setelah iskemia reperfusi pada tikus (Curek et al., 2010). Studi lain menunjukkan bahwa apoptosis dan autophagy yang disebabkan oleh cedera iskemia reperfusi pada hati, dilemahkan oleh astaxanthin pretreatment setelah pengurangan pelepasan ROS dan sitokin 
inflamasi melalui jalur mitogenactivated protein kinase (MAPK) pada tikus (Li et al., 2015). Selain itu, juga didapatkan efek perlindungan astaxanthin pada cedera otak dan miokard setelah iskemia reperfusi (Kishimoto et al., 2016).

\section{SIMPULAN}

Astaxanthin di ketahui dapat memberikan manfaat bagi kesehatan kardiovaskular melalui kemampuannya untuk mengurangi, atau menetralkan produksi ROS sehingga dapat meningkatkan aktivitas enzim pembersih radikal. Astaxanthin juga berperan sebagai anti inflamasi dan berperan dalam metabolisme lipid melalui efek hipokolesterolemik serta melindungi dari iskemia reperfusi.

\section{DAFTAR PUSTAKA}

Alam, M. N., Hossain, M. M., Rahman, M. M., Subhan, N., Mamun, M. A. Al, Ulla, A., Reza, H. M., \& Alam, M. A. (2018). Astaxanthin Prevented Oxidative Stress in Heart and Kidneys of Isoproterenol-Administered Aged Rats. Journal of Dietary Supplements, 15(1), 42-54. https://doi.org/10.1080/19390211. 2017.1321078

Bhuvaneswari, S., Arunkumar, E., Viswanathan, P., \& Anuradha, C. V. (2010). Astaxanthin restricts weight gain, promotes insulin sensitivity and curtails fatty liver disease in mice fed a obesitypromoting diet. Process Biochemistry, 45(8), 1406-1414. https://doi.org/10.1016/j.procbio.2 010.05 .016

Choi, H. D., Kim, J. H., Chang, M. J., Kyu-Youn, Y., \& Shin, W. G. (2011). Effects of astaxanthin on oxidative stress in overweight and obese adults. Phytotherapy

Research, 25(12), 1813-1818. https://doi.org/10.1002/ptr.3494

Curek, G. D., Cort, A., Yucel, G., Demir, N., Ozturk, S., Elpek, G. O., Savas, B., \& Aslan, M. (2010). Effect of astaxanthin on hepatocellular injury following ischemia/reperfusion. Toxicology, 267(1-3), 147-153. https://doi.org/10.1016/j.tox.2009. 11.003

Deng, Z. Y., Shan, W. G., Wang, S. F., Hu, M. M., \& Chen, Y. (2017). Effects of astaxanthin on blood coagulation, fibrinolysis and platelet aggregation in hyperlipidemic rats. Pharmaceutical Biology, 55(1), 663-672.

https://doi.org/10.1080/13880209. 2016.1261905

Doughty, K. N., Del Pilar, N. X., Audette, A., \& Katz, D. L. (2017). Lifestyle Medicine and the Management of Cardiovascular Disease. Current Cardiology Reports, 19(11). https://doi.org/10.1007/s11886017-0925-z

Fassett, R. G., \& Coombes, J. S. (2012). Astaxanthin in cardiovascular health and disease. Molecules, $17(2)$, 2030-2048. https://doi.org/10.3390/molecules 17022030

Garcia-Arellano, A., MartínezGonzález, M. A., Ramallal, R., Salas-Salvadó, J., Hébert, J. R., Corella, D., Shivappa, N., Forga, L., Schröder, H., Muñoz-Bravo, C., Estruch, R., Fiol, M., Lapetra, J., Serra-Majem, L., Ros, E., Rekondo, J., Toledo, E., Razquin, C., Ruiz-Canela, M., ... Sáez, G. 
(2019). Dietary inflammatory index and all-cause mortality in large cohorts: The SUN and PREDIMED studies. Clinical Nutrition, 38(3), 1221-1231. https://doi.org/10.1016/j.clnu.201 8.05 .003

Hussein, G., Goto, H., Oda, S., Sankawa, U., Matsumoto, K., \& Watanabe, H. (2006). Antihypertensive potential and mechanism of action of astaxanthin: III. Antioxidant and histopathological effects in spontaneously hypertensive rats. Biological and Pharmaceutical Bulletin, 29(4), 684-688. https://doi.org/10.1248/bpb.29.68 4

Kishimoto, Y., Yoshida, H., \& Kondo, K. (2016). Potential antiatherosclerotic properties of astaxanthin. Marine Drugs, 14(2), $1-13$.

https://doi.org/10.3390/md140200 35

Lanier, J. B., Bury, D. C., \& Richardson, S. W. (2016). Diet and Physical Activity for Cardiovascular Disease Prevention. American Family Physician, 93(11), 919-924.

Li, J., Wang, F., Xia, Y., Dai, W., Chen, K., Li, S., Liu, T., Zheng, Y., Wang, J., Lu, W., Zhou, Y., Yin, Q., Lu, J., Zhou, Y., \& Guo, C. (2015). Astaxanthin pretreatment attenuates hepatic ischemia reperfusion-induced apoptosis and autophagy via the ROS/MAPK pathway in mice. Marine Drugs, 13(6), 3368-3387. https://doi.org/10.3390/md130633 68
MacEdo, R. C., Bolin, A. P., Marin, D. P., \& Otton, R. (2010). Astaxanthin addition improves human neutrophils function: In vitro study. European Journal of Nutrition, 49(8), 447-457. https://doi.org/10.1007/s00394010-0103-1

Migliaccio, S., Brasacchio, C., Pivari, F., Salzano, C., Barrea, L., Muscogiuri, G., Savastano, S., \& Colao, A. (2020). What is the best diet for cardiovascular wellness? A comparison of different nutritional models. International Journal of Obesity Supplements, 10(1), 50-61. https://doi.org/10.1038/s41367020-0018-0

Ni, Y., Nagashimada, M., Zhuge, F., Zhan, L., Nagata, N., Tsutsui, A., Nakanuma, Y., Kaneko, S., \& Ota, T. (2015). Astaxanthin prevents and reverses diet-induced insulin resistance and steatohepatitis in mice: A comparison with Vitamin E. Scientific Reports, 5(October), 115.

https://doi.org/10.1038/srep17192

Salim, K. P., Indrawati, R., \& Limantara, L. (2016). Terapi Alternatif Penyakit Kardiovaskular dengan Pigmen Alami. 43(11), 871-874.

Santos, S. D., Cahú, T. B., Firmino, G. O., de Castro, C. C. M. M. B., Carvalho, L. B., Bezerra, R. S., \& Filho, J. L. L. (2012). Shrimp Waste Extract and Astaxanthin: Rat Alveolar Macrophage, Oxidative Stress and Inflammation. Journal of Food Science, $77(7)$. https://doi.org/10.1111/j.1750- 
3841.2012.02762.x

Tsai, M. C., Huang, S. C., Chang, W. T., Chen, S. C., \& Hsu, C. L. (2020). Effect of astaxanthin on the inhibition of lipid accumulation in 3T3-L1 adipocytes via modulation of lipogenesis and fatty acid transport pathways. Molecules, 25(16), 1-12. https://doi.org/10.3390/molecules 25163598

Xia, W., Tang, N., Kord-Varkaneh, H., Low, T. Y., Tan, S. C., Wu, X., \& Zhu, Y. (2020). The effects of astaxanthin supplementation on obesity, blood pressure, CRP, glycemic biomarkers, and lipid profile: A meta-analysis of randomized controlled trials. Pharmacological Research, 161(March), 105113. https://doi.org/10.1016/j.phrs.202 0.105113

Yang, Y., Seo, J. M., Nguyen, A., Pham, T. X., Park, H. J., Park, Y., Kim, B., Bruno, R. S., \& Lee, J. (2011). Astaxanthin-rich extract from the green alga Haematococcus pluvialis lowers plasma lipid concentrations and enhances antioxidant defense in apolipoprotein E knockout mice. Journal of Nutrition, 141(9), 1611-1617.

https://doi.org/10.3945/jn.111.142 109 